УАK 17.02

DOI: 10.26565/2226-0994-2019-61-4

\title{
Анастасія Щербакова
}

\section{РЕАБІАІТАЦІЯ ЕТИЧНОГО КРІЗЬ ПРИЗМУ ЗНАЧУЩОСТІ ІНАИВІАУААЬНОЇ БІОГРАФІЇ (А. МАКІНТАЙР, Г. АРЕНАТ)}

Мета Ааної статті полягає у АосліАженні етичної проблематики у філософських роботах А^асдера Макінтайра та Ганни Арендт. 3 одного боку, маємо аналіз етики чеснот та ії місця у сучасному суспільстві крізь призму притаманної цьому суспільству етики емотивізму, 3 іншого - аналіз вчинку та судження як самоцінних сфер саморепрезентації Аюдини. Макінтайр розробляє свою гіпотезу щодо індивідуальної біографії, вказуючи на те, що сучасна етика емотивізму не лишає місця свіАомому етичному світогАяАу, реАукує сферу етичного вибору Ао самого Аише висловлення індивіАуального впоАобання. У такий спосіб́ посліАовність етичних рішень і прихильностей у житті Аюдини набуває характеру ірраціонального та свавільного, коли унеможАивАюється свіАомий перехіА віА оАного наративу Ао іншого. Водночас можливість індивіАуальної біографії як цілісної історії, що мюдина може ії про себе розповісти, передбачає такий змістовний характер етичних погАядів, який має риси наративу, що може бути раціонально розповіАаним і раціонально сприйнятим іншими. Ганна Арендт аналізує проблему сучасної етичної кризи з іншого боку, розглядаючи етичний вимір здатності судження та ролі вчинку в соціальній взаємодії. Вчинок, на Аумку Арендт, постає суто Аюдською сферою Аіяльності, у якій може розкриватися особистість (на віАміну віА сфер праці та створення). 3Аатність судження у цьому контексті постає тим фундаментом, завдяки якому Аюдина стає здатною Ао вчинку: етичне світобачення існує в термінах оцінки певного існуючого по відношенню Ао певного належного. Вчинок у цьому контексті є Аіяльним втіленням певної світоглядної позиції, яка розгортається саме у сфері етичного, будучи залученою до міжлюдської взаємодії. Арендт каже про те, що вчинок за своєю природою є непрогнозованим і що кожна Аюдина, яка на нього наважується, ризикує отримати в піАсумку результат Ауже відАалений від ії намірів. Саме через це вчинок існує одночасно й у біографії актора, і в тканині міжлюдських зв'язків - і саме останні надають поле Аля інтерпретації значущості дій актора. Отже, індивіАуальна біографія постає тим, що набуває сенсу мише крізь призму міжособистісної взаємодії та взаємних інтерпретацій індивіАуальних історій.

Keywords: індивіАуальна біографія, вчинок, суАження, етичний світогляА.

Питання статусу й характеру етичної проблематики в сучасній культурі є вкрай актуальним: одні автори говорять про кризу моралі в сучасному суспільстві, інші вбачають у Аіберальній етиці втілення просвітницьких моральних ілеалів, треті взагалі кажуть про тотальний занепаА і закликають до «віАродження духовності». Специфіка сучасних етичних АосліАжень визначається обставиною так званої «смерті наративу»: етичні системи мають справу з категорією належного, по віАношенню до якого аналізується наявне (у якому в той чи інший спосіб визначається невіАповіАність належному), тож передумовою розгортання етичної системи є готовність до висловАювання однозначних імперативних суджень, крізь призму яких стає можливим аналіз наявного.

Водночас та обставина, що наратив мертвий, унеможливлює таку однозначність, а отже етичні досліАження вимушені в той чи інший спосіб дотримуватися нейтральної позиції. Це означає, що досліАник, аналізуючи цілісність етичної системи, звертається також до тієї особистості, що виступає актором у цій етичній парадигмі: тобто фокус аналізу зміщується 3 абсолютного характеру етичного імперативу на особистість того, хто виступає і носієм цього етичного світобачення, і актором, що він його втілює у своїх діях. Проблема вимушеної нейтральності етичного аналізу порушувалася ще С. К’еркегором

(C) Щербакова А. О., 2019. 
у контексті протиставлення етичного та об’єктивного. Він зазначає, що «<..> вважається надійно Аоведеним, шо об’єктивний намір Аюдини, що схиляє іï Ао того, щоб перетворитися на спостерігача, у сучасному слововживанні вважається етичною віАповіААю на питання, що я маю робити етично. (Бути спостерігачем Аля них також означає бути етичним! Те, що Аюдина має в міру своєї снаги перевтілюватися на спостерігача, і є етичною віАповіАдю, інакше довелося б припустити, що взагалі ніхто не ставить собі питання щодо етичного, а тому й жодної відповіАі тут немає)» [Кьеркегор, 2005, с. 147].

У Ааній статті ми прагнемо Аослідити, як два аспекти етичного в житті Аюдини тобто світоглядний і Аіяльний - АосліАжуються в концепціях зазначених у назві авторів. Йтиметься про етику чеснот в інтерпретації А^асдера Макінтайра та вчинок і судження в концепції діяльного життя Ганни АренАт. Предметом нашого Аослілження буде розгляА єАності цюАського життя або безперервності індивіАуальної біографії як сутнісної точки перетину зазначених концепцій. Саме єАність і безперервність усвіАомлюваного життя та можливість біографії як цілісної історії є тим контекстом, у якому етичне набуває статусу самоцінної сфери самоусвідомлення та Аій Аюдини. Тож метою Ааної роботи є виявлення справеАливості цієї тези крізь призму зазначених концепцій. ЗаАля досягнення цієї мети ми маємо вирішити наступні завдання: (1) дослідити зв’язок судження та вчинку в концепції Арендт та його етичний вимір; (2) Аослідити критику етики емотивізму Макінтайра; (3) проаналізувати «єАність АюАського життя» Макінтайра та «зацученість до тканини міжлюдських зв’язків» Арендт як концептуалізацію індивідуальної біографіі; (4) проаналізувати іАею індивіАуальної біографії та виявити іï значущість Аля можливості свідомого етичного вибору.

Зазвичай концепцію вчинку, що іï Арендт розгортає у своїй «Vita activa або про Аіяльне життя» [Арендт, 2000], пов’язують із цариною соціальної філософії або політичної Аумки. Цей погляА є, звісно, актуальним і сама Арендт, вірогіАно, вбачала характер своєї роботи саме таким. Проте ми маємо намір АосліАити значущість саме етичного виміру вчинку, пов’язуючи його з не менш важливим у філософії Арендт концептом судження, що вона його виводить 3 кантівської естетики. У цьому контексті виАається вкрай цікавим, що концепція вчинку зазнала суттевого впливу арістотелівської етичної та політичної Аумки, яку водночас протистав яють кантівській етиці: цей антагонізм зазвичай позначають як протистав ення етики чеснот етиці боргу (як це робить, наприклаА, А. Макінтайр [Макинтайр, 2000]).

Вчинок або Аія, на думку АренАт, постає особливою формою АюАської Аіяльності, що не є пілпорядкованою критеріям корисності або продуктивності, як це є актуальним Аля сфер праці та створення, яким вона його протистав яє. Саме сфера вчинку є тим простором, завдяки якому Аюдина здійснює значущу саморепрезентативну Аію, що може бути сприйнятою іншими: «Аіючи та говорячи, АюАи кожного разу виявАяють, ким вони є, активно показують особисту неповторність власної сутності, ніби виступають на сцені світу, на якій їх не було так видно раніше, тобто до тієї миті, коли без їхньої в асної участі просто було явлено їхній унікальний тілесний досвіА і не менш унікальний звук їхнього голосу. На віАміну віА того, иим є мюАина, на віАміну віА вАастивостей, обдарованостей, талантів, неАоліків, якими ми володісмо і тому тримаємо в руках піА власним контролем принаймні до тих пір, Аоки ми вільні їх показати або приховати, власне особисте хто вислизає 3-піА нашого контролю, мимоволі виявцяючись у тому, що ми говоримо або робимо» [Арендт, 2000, с. 234]. Вчинок постає одночасно й самоцінним вираженням індивідуальної особистості, i, що $є$ не менш важливим, він відсилає до таких надіндивіАуальних сенсів, які можуть бути сприйнятими іншими.

У мовленні та дії індивіл виражає певну ціннісну позицію - концептуалізація цієї позиції є власне судженням у вельми специфічному сенсі. Витоком концепції судження Аля Арендт слугує кантівська естетика, у якій здатність судження є тим піАгрунтям, завдяки якому стає можАивою категорія естетичного смаку. Проте Арендт каже про те, що така спроможність не може бути приналежною Аише сфері споглядання - вона також слугує 
фундаментом будь-якої етичної оцінки. Тією ж мірою, якою здатність судження забезпечує змістом поняття прекрасного і потворного, вона так само забезпечує змістом оцінки в термінах «добре» та «погано». Ба навіть більше: «У практичних і моральних питаннях воно [судження] зветься “сумління", проте таке сумління не судить, ніби священний голос божества або розуму, воно говорить вам, що робити, чого не робити і в чому каятися. Чим би не був голос сумління, його неможливо назвати “німим", а його Аієвість цілком залежить віА влаАи, що стоїть вище будь-яких законів і правиц простих смертних» [АренАт, 2011, с. 13].

ОАнією з можливих віАповідей на питання про сутність та виток цієї «наАлюдської» влаАи слугує міркування про предмет розуму, що Арендт його розглядає у своїй роботі «Життя розуму». У контексті нашого міркування маємо зазначити Ава важливі моменти стосовно цієї роботи: вона є за своєю структурою суто кантівською (вона складається 3 «Мислення» й «Воління» та мала б завершуватися «Судженням», подібно до трьох кантівських «Критик...»), проте метою роботи є спроба віАповісти на питання, як саме стає можливим зло. Цікаво, що попередні значущі міркування з цього приводу вона надає вже у «Мисленні», ще навіть не торкаючись питання про волю (на віАміну віА Канта, Аля якого вирішальну роль у питанні добра і зла віліграє моральний імператив, що хоча й витікає 3 чистого розуму, проте знаходиться в компетенції чистої волі) та посилаючись на постать Сократа. Вона каже про те, що: «Оскільки пошуки мислення - це своєріАна жаАаюча Аюбов, предметами розуму можуть бути мише ті речі, що викликають Аюбов, - краса, мудрість, справедливість тощо. Потворність і зло за визначенням виключаються зі сфери мислення. Вони можуть проявлятися як неАолік: потворність - це брак краси, зло, kakia, брак Аобра. Як такі вони не мають власного коріння, у них немає сутності, якою б мислення могло оволодіти» [Арендт, 2013, с. 177]. 3 такої постановки питання маємо Аекілька важливих наслідків: мислення, оскільки воно є Аоступним усім розумним створінням, за своєю природою є в цьому сенсі «наАлюАським». Ао того ж, коли йдеться про винесення судження етичної оцінки, воно за своєю організацією є таким, що може бути сприйняте іншими (це, звісно, не виключає можливий «конфцікт інтерпретацій» в оцінці ситуації, проте маємо тут хоча й неточний, але все ж таки критерій, який може бути сприйнятий розумом).

Як бачимо, Аля Арендт сфери етичного та естетичного як у самій «внутрішній» Аіяльності розуму, так і в «зовнішній» сфері судження (говоріння та вчинку) є подібоними одна до одної. Життя розуму є й мишається суто внутрішньою Аіяльністю, що є присвяченою максимально узагальнюючим сутностям, а ось судження, зі свого боку, завжди спрямоване на оцінку часткового, виходячи 3 критеріїв цього узагальнення. Особистісний характер вчинку забезпечується тією рішучістю, яку вияв яя актор, виносячи судження, яке може ставати в опозицію до наявної суспільної ситуації та переконань. Незважаючи на те, що критерії розуму є доступними усім мислячим створінням, саме відмова віА судження постає справжнім витоком зла, коли Аіяльність мислення стає ізольованою від сфери вчинку - коли немає того, хто зАатен відверто вказати на спотвореність наявного положення справ з етичної точки зору.

Тож сфера судження і вчинку постають у специфічний спосіб пов'язаними зі сферою умоглядного. Той спосіб, яким мюдина стає вмотивованою на такий виА залученості та, власне, Аіяльного життя, ретельно, на нашу думку, проаналізовано в творах Макінтайра. Значущість та самоцінність культивації певних чеснот стає тією канкою, яка формує Аіяльне віАношення до певного наративу (коли йдеться не про одиничний вчинок, якого потребують обставини, але про зАатність Ао вчинку як певний спосіб життя). Проте в сучасній ситуації кризи етичного самоцінність такої культивації скцадно Аовести: суспільство вітає зАатність до аАаптації, зАатність знаходити вихіА з будь-якої ситуації, якого б ціннісного протиріччя вона не потребувала. Витоки цієї проблеми з актуальними Аля нашого АосліАження акцентами Макінтайр розглядає у своій відомій праці «Після чесноти: АосліАження теорії моралі», аналізуючи сутнісні риси етики емотивізму (яка 
в концепції Макінтайра віАіграє вирішальну роль Аля характеристики сучасної етичної ситуації: як на рівні філософських етичних рефлексій, так і на рівні повсякденного етичного АосвіАу сучасної Аюдини).

Емотивізм, на думку Макінтайра, зводить будь-яке етичне судження до самого Аише висловлення особистого вподобання. Тобто етика емотивізму стверджує, по-перше, що будь-яке етичне судження якщо й віАсилає Ао якогось усім віАомого (і такого, що поділяється певною спільнотою) ціннісного положення, то, незважаючи на це, воно є, насамперед, вираженням особистого ірраціонального вподобання. 3 цього витікає важливий насліАок, через який емотивізм зАійснюе перегортання «класичної» етичної парадигми: він нівелює різницю між самоцінністю особистості та можливого Аіапазону етичних Аій, які можуть бути на неї спрямовані, та власне маніпулятивною Аією [Макинтайр, 2000, с. 35-37].

Маніпулятивна Аія передбачає, що один індивіА прагне використати іншого як засіб Аля досягнення вцасної мети: задля цього він може апелювати до певної ціннісної позиції, але це апелювання зостається самою мише волею до влади. Отже, той простір, у якому певна спільнота може поділяти певні цінності, формується не завдяки вільному вибору іï членів, а Аише завдяки чиійсь волі, яка змогла завдяки власній харизмі піАкорити інших. Макінтайр стверджує, що сучасна ситуація етичного своїми сутнісними рисами зобов'язана саме емотивістській етиці та нівелюванню різниці між маніпулятивною i неманипулятивною дісю: «Якщо емотивізм є вірним, тоді ця різниця є ілюзорною. Тому що оцінювальний вислів може не мати будь-якого іншого вживання, за винятком висловлювання позиції та моїх власних почуттів або впливу на почуття та позиції інших Аюдей. Я не можу по-справжньому апелювати Ао позаособистісних критеріїв, тому що таких критеріїв немає» [Макинтайр, 2000, с. 36].

Крім того, сутнісною рисою етики емотивізму є постулювання принципово віАокремленої особистості, Аля якої залученість Ао суспільних віАносин або просто стосунків із іншими Аюдьми постає Аише соціальними ролями - «масками», що Аишаються суто зовнішніми. Посилаючись на Вебера, Макінтайр аналізує такі «характери» сучасної культури, як менеджер та терапевт. Незважаючи на те, що обидві ролі передбачають, що їхні носії за специфікою своєї професійної Аіяльності мають справу з Аюдьми, ці «носії» мають у своїй Аіяльності керуватися, насампереА, не етичними принципами (виключаючи звідси юридичні вимоги щодо медичної етики Аля терапевта), а методологією, завдяки якій може бути досягнута максимальна ефективність: «Ані менеджер, ані терапевт у своїх віАповіАних ролях не беруть участь у моральних дебатах - та й не можуть брати в них участь. Вони та Аюди, які АОтримуються однакових з ними погАядів щодо цього, вважають себе фігурами поза конкуренцією, чиєю метою є обмеження себе сферами, де є можливою раціональна згода: сферою фактів, сферою засобів, сферою вимірювальної ефективності» [Макинтайр, 2000, с. 36]. Тобто в світоглядній позиції менеджера та терапевта втілена принципова відмова віА судження, а отже й віА вчинку.

Окрім тієї обставини, що сучасна етична ситуація продукує сфери міжособистісної взаємодіï, які опиняються «по той бік» етичного як певної сукупності внутрішніх намірів та цінностей актора (а позірно вони, звісно, мишаються впорядкованими, бо регулюються правом), важливо зазначити «симптоматичний» момент, що витікає з наведеного уривка: характеристиками взаємодіï, що позначаються як мислимі («раціональна згода») Аля менеджера та терапевта, є факти, засоби та ефективність, натомість власне ціннісне судження виноситься до сфери ірраціонального та вкрай індивіАуального. Тож і судження, і вчинок або зостаються поза межами такого дискурсу (не маючи термінів, у яких би вони могли бути описані, не втрачаючи свого сенсу та не редукуючись через оцінку їх у термінах ефективності, корисності чи продуктивності), або інтерпретуються в термінах індивіАуального вподобання.

Своєрідну реабілітацію власної сфери вчинку проводить і Макінтайр, і Арендт, звертаючись до поняття історії та біографії: 3 тією різницею, що Арендт цікавить 
невіл'ємна залученість індивіда, що діє та говорить, Ао «тканини загальнолюдських зв’язків», а Макінтайр концептуалізує цю сферу за допомогою «єАності АюАського життя».

Щодо Арендт, то в ії досліАженнях йдеться про те, що вчинок втілюється у сфері наявних міжлюдських зв'язків, і ані сам актор, ані ті, хто перебувас піА впливом його вчинку або насліАків останнього, не можуть спрогнозувати результатів цього вчинку. ВАасне, результат вчинку може зрештою мати мише дуже опосередковане віАношення до тих мотивів, що спонукали актора Аіяти. Проте вчинок певним чином «впАітається» Ао наявної сітки міжлюдських зв'язків і внаслідок цього «вплітання» він формує індивіАуальну історію актора, а також тих, хто потрапив піА вплив Ааного вчинку. Ао того ж значущість вчинку неможливо оцінити безпосередньо тоді, коли він втілюється. Це можна зробити мише в контексті тієї історії, яку про нього розповіАатимуть надалі. Ця значущість має також і окремий сенс Аля біографії актора, бо тут йдеться вже не про одну з багатьох історій, а про біографію його власного життя, яке він проживає.

Коли Макінтайр акцентує увагу на єАності АюАського життя, він також звертається Ао поняття біографії як особистої історії та каже про те, що етика емотивізму певною мірою нівелює можливість побачити таку індивіАуальну історію як єАність: «< ..> емотивістське Я у своєму переході віА одного стану моральної прихильності до іншого може не мати раціональної історії. Внутрішні конфлікти є Аля нього необхіАно глиббоким зіткненням оАного випадкового свавілАя 3 іншим. Це Я без заданих безперервностей, за винятком тіла, яке є носієм Я та пам'яті, що акумулює найкращим чином попереднє Я. А 3 робіт по проблемі особистісної тотожності

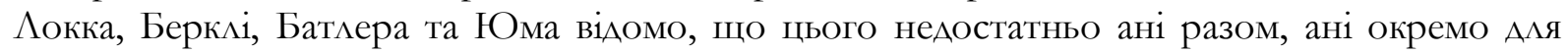
специфікації такої тотожності та безперервності, у яких є таким впевненим наше реальне Я» [Макинтайр, 2000, с. 52-53]. Така ситуація водночас продукує суб’єкта, який не може в раціональний спосіб знайти достатніх піАстав Аля значущості вчинку, тож на рівні свіАомої рефлексії він видається нездатним обгрунтувати й втілити в життя будь-яке етичне судження. Він не може сформувати 3 послідовності своїх життєвих рішень таку безперервність АосвіАу, яка могла б оминати «точки розриву» 3 протиріч між тими наративами, якими він керувався в той чи інший період життя. Отже, він не має цілісної історії, яку можна було б про себе розповісти.

Звісно, ми не маємо тут на увазі, що Аюдина наразі взагалі не може Аіяти. Проте вона опиняється в особливій ситуації особистісного трагізму: будь-яка спроба Аля неї обгрунтувати вАасний вибір у термінах будь-якого гатунку ціннісної парадигми (тобто термінах, які віАсилали б до певних етичних уявлень, що їх поділяе певна спільнота або сукупність Аюдей) кожного разу реАукується до самого Аише «інтересу», «вподобання» або навіть «можливої користі». Якщо Аля Арендт простір вчинку постає самоцінною сферою власне Аюдського, а Аля Макінтайра в цій ролі опиняються чесноти 3 практиками, що в них вони культивуються, то Аля парадигми емотивізму не існує такої сфери самоцінного в міжлюдській взаємодії, яка б не мала бути редукованою до суто індивідуальних вподобань. Самоцінність в обох позиціях постулюється не Аише в міжлюАській взаємодії, але й також є тим, завдяки чому індивід може усвідомлювати самого себе, бо в інших сферах, Ае його Аії є зорієнтованими на отримання конкретного результату, він у певному сенсі постає засобом Аля досягнення конкретної мети, а цінність його дій вимірюється успішністю в Аосягненні результату. Звісно, кажуть про «цінний АосвіА» у разі невАаАої спроби Аосягти чогось: у цьому, Ао речі, внутрішній досвіА індивіАа виокремлюється у щось значуще. Проте така риторика зазвичай передбачає, що цей досвіА може наАалі бути використаним більш вдало - тож навіть тут критерій успішності опосередковано мишається керуючим.

На принципову неможливість зведення певної людської Аіяльності до такої, що мислиться в термінах «корисності» та «результативності», Арендт вказує піА час АосліАження Аюдської здатності починати щось нове. Вона каже про те, що здатність починати щось принципово нове - таке, що не може в усій повноті свого змісту бути 
вписаним до наявної сукупності причинно-наслідкових зв'язків - є ще одним суттєвим аспектом Аля вчинку та Аіï. Звісно, ми не можемо тут казати, що таке «починання» розгортається цілком незалежно віА зовнішніх впливів, проте будь-яка сукупність зовнішніх обставин потенційно може бути інтерпретованою крізь призму різноманітних наративних історій і нам заздалегіАь невіАомо, яку саме вибере актор.

Проти «утилітаристичної» редукції також виступає Макінтайр, вказуючи на те, що незважаючи на сутнісний взаємозв’язок між чеснотами та практиками, у яких вони культивуються, Ауже часто виявляється, що індивіАуаАьна культивація певних чеснот (у сенсі формування характеру завдяки намаганням втілити у власній поведінці та світосприйнятті певні чесноти) часто опиняється в ситуації певного дисонансу з тією практикою, у якій вона ж є культивованою. ЙАеться про те, що бюрократичний характер практики може створювати ситуації, коли культивація навіть притаманної цій практиці чесноти може опинятися «по той бію» наявної бюрократичної системи, через що розвивається практика - саме такі ситуації призводять до внутрішніх змін бюрократичного апарату.

Культивація чеснот, у інтерпретації Макінтайра, постає певною Ауховною практикою, яка керується ціннісним вибором на користь певної чесноти. Водночас самі чесноти є зоріснтованими, звісно, на простір етичного, але Аля них є характерним принципово естетичний компонент: культивація чеснот є практикою, націленою на формування певної особистості, певного характеру та образу індивідуальної поведінки, завдяки чому формується історія життя, яку мюдина розповідає про себе. Ця історія сприймається та оцінюється одночасно як ціннісна позиція, яку (з етичного погляАу) можна обрати, і як образ в^асної особистості - ідеальний (з естетичної точки зору) та який можна насліАувати. Тож біографія постає полем самоінтерпретації суб'єкта, а можливість усвідомлення іiі єАності - тим Ажерелом, завАяки якому АюАина сама Аля себе постає зАатною Ао свіАомого судження.

Отже, етична сфера в аргументації обох авторів виявляється такою, що існує поза межами термінологічного апарату емотивістської або утилітарної етики. А^я Арендт у цьому сенсі є принциповою відмежованість сфери вчинку віА термінологічної сітки, що передбачає аналіз у термінах «результативності» та «корисності», а Аля Макінтайра - віА редукції етичного Ао «особистого інтересу» та «індивіАуальної віАокремленості». У цьому протиставленні сфера етичного набуває певної самоцінності, але оскільки індивіА, що Аіє, не може ані спрогнозувати, ані гарантувати певних «позитивних» результатів обраного способу Аіï, його єАиним критерієм вибору слугує значущість вибору на користь певного вчинку або способу життя в контексті його особистості, його вАасної біографії.

Біографія постає специфічною єАністю внутрішнього та зовнішнього - історією не самих мише Аій, рішень та їхніх насліАків, але й суто внутрішніх намірів, ціннісних орієнтацій та прихильностей. Притаманна сучасній ситуації Аюдини та суспільства культивація цілераціонального способу Аії створює скрутні умови і Аля етичного як такого, і Аля його екзистенціальних вимірів у контексті біографії особистості, аАже ми не маємо гарантій досяжності результату (а інколи не маємо й конкретної мети). Ми керуємося самим мише способом дії (як це відбувається 3 позиції етики чеснот) або відкликаємося на імперативну вимогу зробити хоча б щось, коли усі інші лишаються байАужими.

\section{СПИСОК ВИКОРИСТАНИХ АЖЕРЕ}

АренАт X. Vita activa, или О деятельной жизни / пер. с нем. и англ. В. В. Бибихина. СПб.: Алетейя, 2000. 437 с.

Арендт Х. Жизнь ума / пер. с англ. А. В. Говорунова. СПб.: Наука, 2013. 517 с.

Арендт Х. Аекции по политической философии Канта / пер. с англ. А. Гцухова. СПб.: Наука, 2011. 303 с.

Кант И. Аекции по этике /пер. с нем., общ. реА., сост. и вступ. ст. А. А. Гусейнова. М.: Республика, 2000. 431 с. 
Кьеркегор С. Заключительное ненаучное послесловие к «Философским крохам» / пер. с Аатского Н. Исаевой и С. Исаева. СПб.: ИзА-во С.-Петерб. ун-та, 2005. 680 с.

Кьеркегор С. Равновесие межАу эстетическим и этическим в развитии мичности. Кьеркегор С. Или - или. Фрагмент из жизни: в 2 и. / пер. с дат., вступ. ст., коммент., примеч. Н. Исаевой и С. Исаева. СПб.: ИзАательство Русской Христианской Гуманитарной Академии: Амфора. ТИА Амфора, 2011. С. 632-807.

Макинтайр А. После добродетели: Исследования теории морали / пер. с англ. В. В. Целищева. М.: Академический проект; Екатеринбург: Аеловая книга, 2000. URL: http://rebels-library.org/files/posle_dobrodeteli.pdf.

\section{Щербакова Анастасія Омександрівна}

бакалавр філософіiі, кафелра теоретичної і практичної філософії

імені професора Й. Б. ШаАа

Харківський національний університет імені В. Н. Каразіна

м. Свободи, 6, Харків, 61002

E-mail: shcherbacova1813@gmail.com

ORCID: https://orcid.org/0000-0003-4361-3045

Стаття надійшла до редакції: 26.09.2019

Схвалено Ао Аруку: 08.11.2019

\section{РЕАБИАИТАЦИЯ ЭТИЧЕСКОГО СКВОЗЬ ПРИЗМУ ЗНАЧИМОСТИ ИНАИВИАУААЬНОЙ БИОГРАФИИ (А. МАКИНТАЙР, Х. АРЕНАТ)}

\section{Щербакова Анастасия Александровна}

бакалавр философии, кафелра теоретической и практической философии имени профессора И. Б. ШаАа

Харковский национальный университет имени В. Н. Каразина

пл. Свободы, 6, Харьков, 61002

E-mail: shcherbacova1813@gmail.com

ORCID: https://orcid.org/0000-0003-4361-3045

Цель данной статьи заключается в исследовании этической проблематики в философских работах Аласлера Макинтайра и Ханны Арендт. В частности, речь идет о роли, которую оба автора отводят индивиАуальной биографии и еАинству человеческой жизни в формировании целостного и рефлексивного этического мировоззрения, способности Аичности выносить этические сужАения и, собственно, готовности к поступку, в основание которого актор полагает этические соображения. Кроме того, отАельно анализируются истоки кризиса этического в современном обществе, Аля преодоления которого авторы предлагают новый взгляд на проблему инАивиАуальной биографии и вовлеченности человека в пространство этического Аействия.

КАючевые слова: индивилуальная биография, поступок, суждение, этическое мировоззрение.

Статья поступила в редакцию: 26.09.2019

Утверждена к печати: 08.11.2019

\section{REABILITATION OF ETHICS THROUGH THE PRISM OF INDIVIDUAL BIOGRAPHY (A. MACINTYRE, H. ARENDT)}

Shcherbakova Anastasiya O.

Bachelor of Philosophy, Department of Theoretical and Practical Philosophy

named after Professor J. B. Schad

V. N. Karazin Kharkiv National University

6, Svobody sqr., 61022, Kharkiv, Ukraine

E-mail: shcherbacova1813@gmail.com

ORCID: https://orcid.org/0000-0003-4361-3045 


\begin{abstract}
The purpose of the article is to study ethical problematics in the philosophical works of Alasdair MacIntyre and Hannah Arendt. On the one hand we have the analysis of virtues ethics and of its place in modern society (through the prism of emotivism ethics inherent to this society), and on the other hand, we have the analysis of action and judgment as scopes of person's self-representation, which are valuable by themselves. MacIntyre developed his hypothesis about an individual biography pointing out that modern emotivism ethics does not leave a room for conscious ethical worldview, reduces the scope of ethical choice to the very statement of individual preference. By that, a sequence of ethical decisions and preferences in a person's life acquires irrational and wayward nature, due to which conscious transition from one narrative to another becomes impossible. In its turn, the possibility of individual biography as a holistic story that everyone can tell about themselves provides such an informative nature of ethical views, which have features of a narrative that can be rationally told and rationally perceived by others. Hannah Arendt analyzed the issue of modern ethical crisis from the other side - she studied the ethical dimension of judging ability and the role of action in social interaction. An action (as Arendt believed) becomes the strictly human scope of human activity, in which personality can "open up" (unlike the areas of work and creation). Judging ability appears in this context as a foundation, thanks to which a person becomes able to act: ethical worldview exists in terms of evaluation of something that exists in relation to something due. An action in this context is an active embodiment of a certain worldview position that "unfolds" itself precisely in the area of ethics while being involved in interpersonal interaction. Arendt claimed that an action, due to its nature, is unpredictable and that every human being, who dares to take it, risks getting, in the end, a result that is far from their intentions. Exactly because of it, an action exists in the actor's biography and the fabrics of interpersonal connections simultaneously - it is the latter, which gives the space for interpretation of an actor's actions significance. Thus, the individual biography becomes the thing that makes sense only through the prism of interpersonal interaction and mutual interpretations of individual stories.
\end{abstract}

Key words: individual biography, action, judgment, ethical outlook.

\title{
REFERENCES
}

Arendt, H. (2000). Vita Activa or about Efficient Life. (V. Bibikhin, Trans.). Saint Petersburg: Aletheia. (Original work published 1958). (In Russian).

Arendt, H. (2013). The Life of the Mind. (A. Govorunov, Trans.). Saint Petersburg: Nauka. (Original work published 1977). (In Russian).

Arendt, H. (2011). Lectures on Kant's Political Philosophy. (A. Gluhov, Trans.). Saint Petersburg: Nauka. (Original work published 1982). (In Russian).

Kant, I. (2000). Lectures on Ethics. (A. Huseynov, Trans.). Moscow: Respublika. (In Russian).

Kierkegaard, S. (2005). Concluding Unscientific Postscript to Philosophical Fragments. (N. Isaeva, S. Isaev, Trans.). Saint Petersburg: Saint Petersburg State University Publishing House. (In Russian).

Kierkegaard, S. (2011). The Balance between Esthetical and Ethical in the Person's Development. In S. Kierkegaard, Either/Or. The Fragment of Life: in 2 parts. (N. Isaeva, S. Isaev, Trans.). Saint Petersburg: Russian Christian Humanistician Academy Publishing House; Amphora. (In Russian).

MacIntyre, A. (2000). After Virtue: Investigations of Moral Theory. (V. Selishchev, Trans.). Moscow: Akademichesky Proekt. Retrieved from http://rebelslibrary.org/files/posle_dobrodeteli.pdf. (Original work published 1981). (In Russian).

Article arrived: 26.09.2019

Accepted: 08.11.2019 